\title{
The State of E-Business in Slovenian Public Administration: The Case of Administrative Units
}

UDK: 659.2:004:35(497.4)

\author{
Mitja Jelenič \\ Administrative Unit Novo mesto \\ mitja.jelenic1@gov.si \\ Mirko Vintar \\ University of Ljubljana, Faculty of Administration \\ mirko.vintar@fu.uni-li.si
}

\section{ABSTRACT}

Over the last few years e-government in Slovenia has experienced very rapid development, with the latest EU surveys showing that Slovenia is among the most advanced member states in this field. However, the actual use of public e-services lags far behind the growing supply. This paper offers a comparative analysis of the current state of affairs in this field in Slovenia, focusing on the country's administrative units. That analysis is based on the results of empirical research into the administrative units' e-business, which was carried out in the first half of $\mathbf{2 0 0 9}$ by the Institute for Public Administration Informatisation at the Faculty of Administration. The research looked at e-business in the most typical areas of the administrative units' work, such as internal affairs, the environment and physical planning, agriculture etc., which most accurately reveal the current state of e-business in Slovenia's public administration, particularly insofar as it relates to operations with citizens. The paper also examines the e-business of administrative units in their internal operations and in operations with other administrative bodies. The final part includes a comparison of the results of the empirical research with the latest results from the EU Capgemini Benchmark study (Capgemini, 2009), as well as a number of other international studies.

$\begin{aligned} & K e y w o r d s: \text { e-government, public e-services, use of public e-services, } \\ & \text { administrative units }\end{aligned}$

\section{JEL: $Z 00$}

Jelenič, M. \& Vintar, M. (2011). The State of E-Business in

Slovenian Public Administration: The Case of Administrative Units.

Uprava, IX(1), 63-84. 


\section{Introduction}

Slovenia has made good progress in introducing new information and communications technologies in its public administration over the last 10 years. The necessary laws and implementing regulations governing electronic business have been adopted, the required computer infrastructure has been put in place and the national e-government portal, which provides many electronic public administration services for various users, has been set up.

At the national level the area which has been given most attention since 2001 has been the development of electronic services for businesses and citizens. The EU, too, has paid particular attention to the development of these services. In the member states and candidate countries it began to systematically monitor this area on the basis of measurements which it commissioned the consultancy company Capgemini to draw up, and which Capgemini has been conducting since 2001. The measurement model, based on a sample of 20 services (eight for businesses and 12 for citizens) to determine the level of development of this area in a particular country, is not ideal and, as the company itself has acknowledged (Capgemini, 2009), will need a thorough overhaul in future. The model has been twice updated in recent years (in 2007 and 2009), with the more recent upgrade being particularly wide-ranging, so the latest results provide a somewhat more realistic picture than those from two years ago and even earlier. Nevertheless, there are many doubts about the accuracy of these results (Bannister, 2007), and especially about those concerning Slovenia because the country has risen rapidly up the rankings of the 30 or so countries in which these surveys have been conducted in recent years. For example, whereas in 2005 it was still in 15th place in terms of "sophistication of online services", by 2007 it had leapt into an enviable second place (behind Austria). Slovenia's result was somewhat poorer in 2009, but its fifth place still means it is among the best performers in the EU. There is nothing wrong with these results if they are taken in the context they relate to, i.e. the 20 selected e-government services, but because in recent years the results of these measurements have been increasingly generalised and equated with the level of development of e-government in Slovenia, both in general and in comparison with other EU countries, they can be problematic, or even misleading, especially as there are a whole range of other indicators 
(e.g. The Economist, 2007; UN E-Government Survey, 2008), which suggest that, in fact, the state of e-government in Slovenia is not so rosy.

In order to obtain a more realistic picture of the state of e-government in Slovenia, particularly from the point of view of the actual use of eservices, in the first half of 2009 the Institute for Public Administration Informatisation devised and implemented empirical research into the situation in Slovenia's administrative units, which are the area of public administration that has the most direct contact with citizens and which handles three-quarters of all public services for citizens and businesses. Consequently, we believe that the electronic operations of these administrative units (with the exception of the Tax Administration) are probably the best indicator of the extent to which e-government has actually taken off. The Capgemini measurements are mainly aimed at determining the offer of services in individual countries, but in practice it is the use of e-government services which tells us more about their actual level of development. And it is precisely the low level of use of egovernment services (Eurostat, 2007a, 2007b), especially those aimed at citizens, which, according to the latest findings, is one of the biggest weaknesses.

This paper aims to examine and comparatively analyse the development of e-government in Slovenia on the basis of the actual use of e-services in certain key areas for the functioning of the administration, and to determine whether we can be happy with the state of development of e-government, particularly in the light of Slovenia's high position in the EU rankings. We will attempt to compare the results of international research with the results we obtained through our own empirical research conducted in the administrative units in Slovenia in 2009. Chapters 2 and 3 describe our own research and the results it produced, and in Chapter 4 we seek to evaluate those results and put them in the broader context of the state of e-government in the Slovenian public administration.

\section{Methodological design of the empirical research}

The main purpose of the empirical research on which this paper is based was to establish the actual state of e-government in the administrative units. We were primarily interested in:

- the administrative units' e-business with their most important service users, i.e. citizens and businesses (external aspects), 
- the areas of the administrative units' operations in which ebusiness is most advanced,

- the administrative units' e-business with other administrative bodies (internal aspect).

In the research carried out at the Institute for Public Administration Informatisation we tried to determine the actual frequency with which electronic applications are received in each of the administrative units' areas of work, and then to analyse in detail the frequency of the individual types of electronic applications and the differences in the frequency with which they are received. One of the basic conditions for achieving the highest level of development of e-operations (stage 4 - transaction, according to the Capgemini model (Capgemini, 2009)) is the possibility of electronic delivery of documents. The regulatory and technological conditions have been in place for some time, so we attempted with the aid of empirical research to determine the extent to which this is actually being carried out in the administrative units' operations in practice.

The state of e-government in Slovenia is indicated not solely by the external supply and use of e-services by citizens, businesses and other organisations, but also by the use of e-business between administrative bodies. Therefore our research also sought to determine how far this internal aspect of e-business has been developed. In the final part of the empirical research we looked at the electronic storage of documents, which presents a growing problem for the e-business of administrative bodies.

The data was collected using a questionnaire sent to the official email addresses of all 58 administrative units in Slovenia. The questionnaire focused on eight key questions, with each question further broken down into the individual areas of the administrative units' operations. The questionnaire was designed to be completed either in electronic form or on paper. The question about how often the administrative units receive individual electronic applications was broken down into the most important areas of the administrative units' operations in terms of volume of business:

- internal affairs

- the environment and physical planning

- agriculture, forestry and food 
- business

- war veterans, victims of war violence and war invalids

- other areas (mainly matters concerning public information).

The completed questionnaire could be returned by e-mail or printed and sent by post. The survey was carried out in April and May 2009. A total of 39 administrative units $(67.24 \%)$ responded to the request to complete the questionnaire and so the sample was sufficiently representative for us to make generalisations on the basis of the research results and extrapolate certain general characteristics of the administrative units' e-business. Of the 39 administrative units, $82 \%$ returned the questionnaire by e-mail, while the other $18 \%$ still opted for ordinary post (Graph 1). The data obtained from the questionnaire were processed in Excel.

\section{Graph 1: Response method ( $N=39$ )}

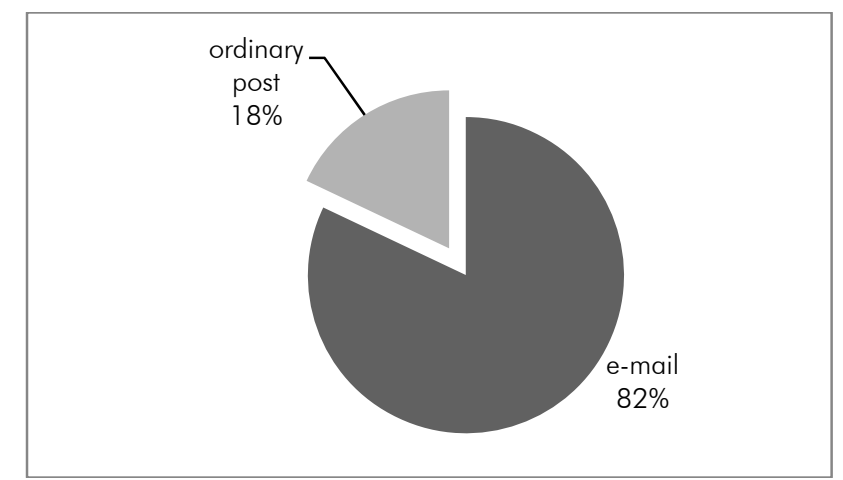

Source: Survey

\section{Research results}

In the first part of the research we were mainly interested in how often the administrative units receive electronic applications and in what areas most electronic applications are received. We also sought to investigate the extent to which electronic delivery is established in practice. This gives us a relatively clear picture of the actual level of development of external e-business, i.e. with citizens and businesses. This part of the research is set out in detail in Chapter 3.1. 


\subsection{Administrative units' e-business with citizens and businesses}

Graph 2 shows the frequency of receipt of various e-applications. For matters relating to internal affairs $47 \%$ of administrative units receive eapplications daily, $21 \%$ weekly, $8 \%$ monthly, $21 \%$ very rarely and one administrative unit has not yet received any such e-applications. On issues concerning the environment, one administrative unit (2.56\%) receives eapplications practically every day, $8 \%$ receive them weekly, $5 \%$ monthly and 28\% more rarely. Most administrative units (56\%) have not yet received any e-applications in this area. For agricultural and forestry matters a small percentage (5\%) of administrative units receive eapplications very frequently, and the same percentage receive them on a weekly basis. Slightly more (11\%) receive applications on a monthly basis, but the percentage of administrative units that receive such applications very rarely is even higher (34\%), while even more (44\%) have never received such applications. E-applications concerning business matters are very frequent at only one administrative unit (3\%), while somewhat more administrative units (8\%) receive them weekly, 5\% monthly and 22\% receive them very rarely. By far the highest proportion (62\%), however, have not yet received any such applications. E-applications concerning war veterans, victims of war violence and war invalids are very frequently received by $5 \%$ of administrative units, only $3 \%$ receive them weekly and $5 \%$ monthly, while most receive them either very rarely $(39 \%)$ or not at all (47\%). Eight administrative units $(21 \%)$ also indicated that they receive e-applications in other areas of their work. Two administrative units replied that they did not receive any e-applications, while the other 29 administrative units did not reply to this question. One administrative unit very rarely receives electronic submissions in the form of praise for public officials and requests for access to public information. Three administrative units receive public information, general information and applications to store documentary or archive material on a weekly basis. One administrative unit replied that it very often receives e-applications relating to its joint services department. 


\section{Graph 2: Frequency of receipt of e-applications by area}

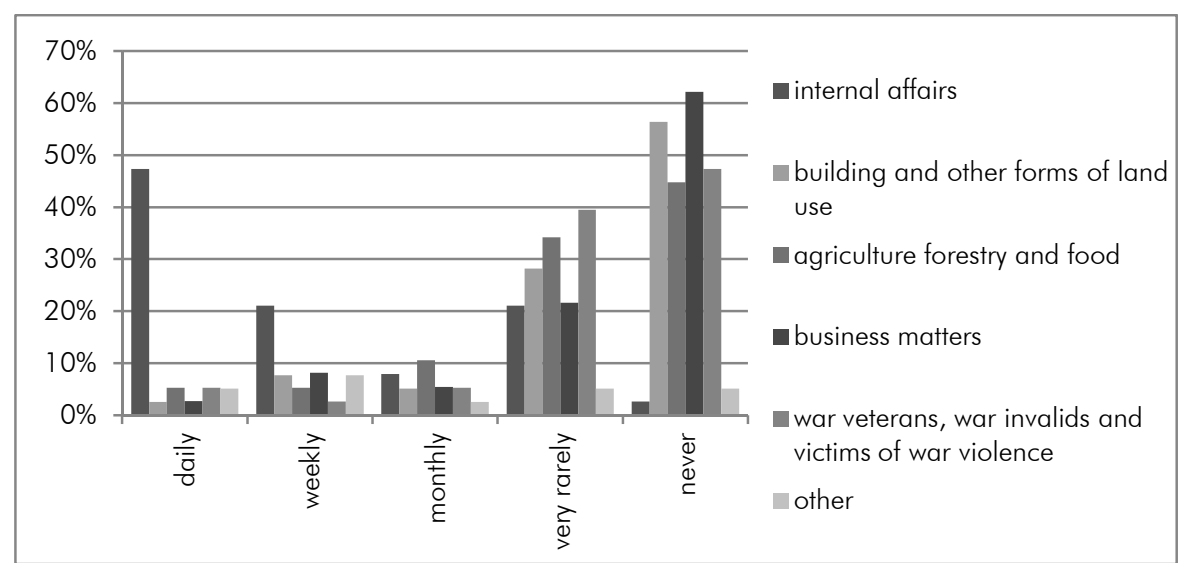

Source: Survey

Only $8 \%$ of administrative units (Graph 3) indicated that they deliver documents electronically to secure electronic mailboxes. It should be pointed out that a secure electronic mailbox does not mean an ordinary e-mail address supplied by an internet provider, but a secure mailbox which is currently only offered by the Slovenian Post Office. Some 10\% of administrative units deliver electronically only in the case of certain documents, while $64 \%$ of administrative units do not deliver documents electronically because they do not believe the IT system allows it. The 18\% of replies entered under "other" can also be included in this category. The explanations given were as follows: e-government does not have a conversion program for e-signed documents because clients do not have a secure electronic mailbox; the IT system does not yet allow this and there has not yet been such a case; no appropriate technical solutions are available. One administrative unit did not give any reason. 


\section{Graph 3: Electronic delivery of documents}

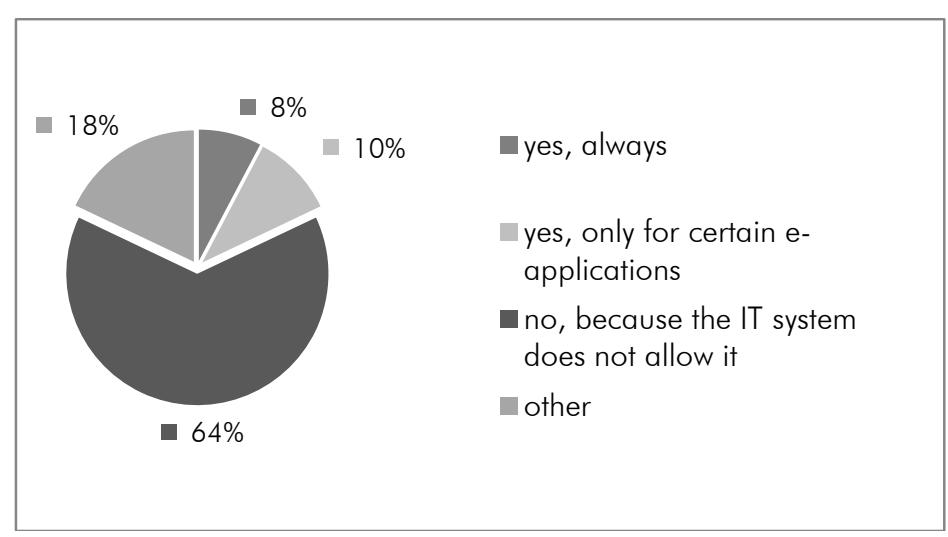

Source: Survey

\subsubsection{Internal affairs}

Of the administrative units which receive e-applications for extending a vehicle registration certificate, the largest number receive them frequently $(21 \%)$, fewer receive them very frequently $(8 \%)$ or occasionally (3\%), and $8 \%$ of administrative units rarely receive them, while $61 \%$ have never received an e-application to extend a vehicle registration certificate. Requests for extracts and certificates from the Central Register are received very frequently by $8 \%$ of administrative units, frequently by $29 \%$, occasionally by $18 \%$ and rarely by $39 \%$, while $5 \%$ of administrative units have never received such applications. For residence certificates and household certificates the frequency is quite evenly distributed: $8 \%$ of administrative units receive applications daily and $16 \%$ frequently, while somewhat more (29\%) receive them occasionally and the largest proportion (34\%) rarely; $13 \%$ of administrative units have not received such applications. Applications to register or deregister permanent residence are not received on a daily basis by any administrative unit; $16 \%$ receive them weekly, $32 \%$ monthly and $42 \%$ rarely. The proportion of administrative units which have not yet received any such applications is $11 \%$. E-applications to change a person's name are very rare. None of the administrative units receives such applications very frequently or even frequently. Even occasionally they are only received by a few administrative units (8\%), while a larger proportion have so far received the occasional application (21\%). So the largest proportion (71\%) have not yet received any such applications (see Graph 4). 
Graph 4: E-applications received for internal affairs $(N=39)$

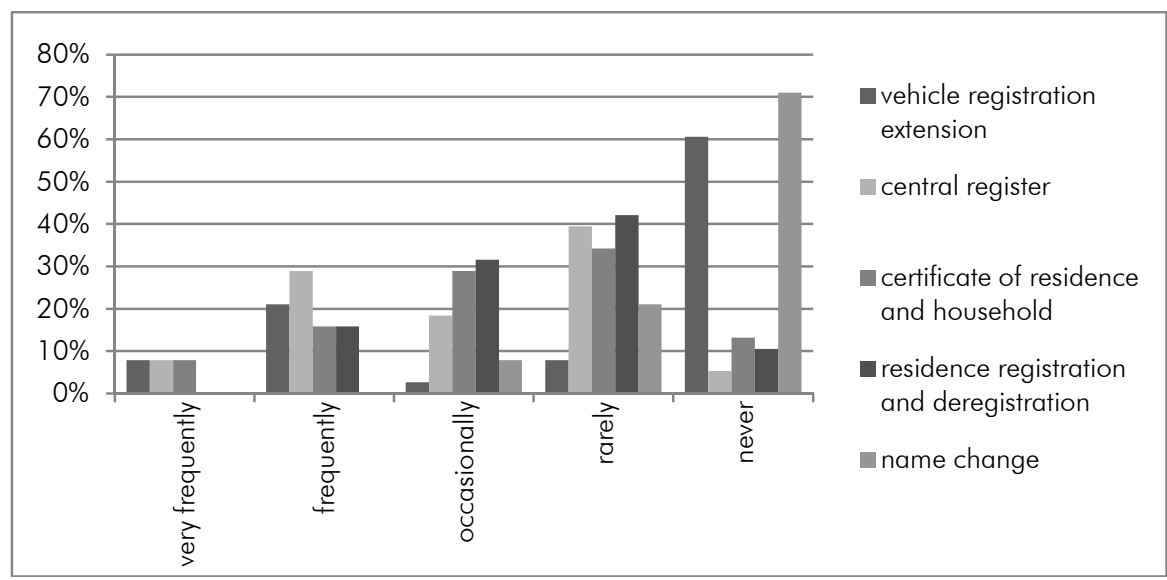

Source: Survey

\subsubsection{Environment and physical planning}

E-applications for construction permits are not frequent, with no administrative unit receiving them on a daily, weekly or even a monthly basis. So far $15 \%$ of administrative units have received such applications, while $85 \%$ have not yet had the opportunity to process them (see Graph 5).

\section{Graph 5: E-applications received for environmental and physical planning} matters $(\mathrm{N}=39)$

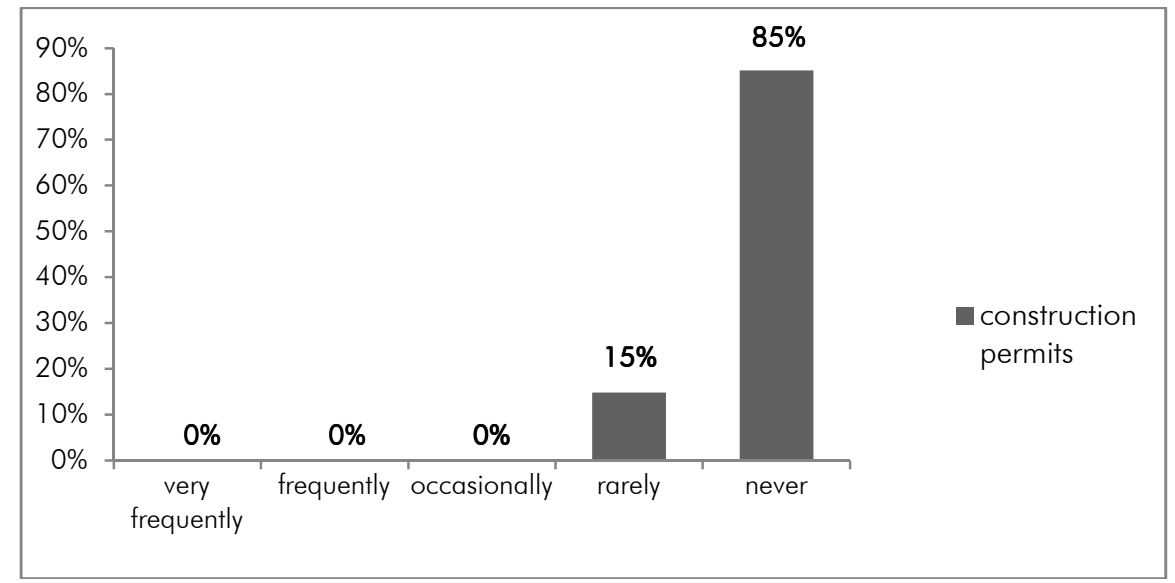

Source: Survey 


\subsubsection{Agriculture, forestry and food}

The results of the survey show (Graph 6) that no administrative units receive applications in this field on a daily or weekly basis. Only offers to sell land (3\%) and applications to enter a member in the register of agricultural households (5\%) are received occasionally, while more administrative units (29\%) receive such applications rarely and even more (61\%) have never received them. Applications to register as a farmer are still infrequent - only 13\% of administrative units have received them, while the other $87 \%$ have never received such applications electronically. The situation is the same with supplementary activities.

Applications to enter a member in the register of agricultural households are received occasionally by $22 \%$ of administrative units, but have never been received by $73 \%$. Some $5 \%$ of administrative units did not respond on this point, and on the other three points in each case one administrative unit did not respond.

\section{Graph 6: E-applications received for environmental and physical planning matters $(\mathrm{N}=39)$}

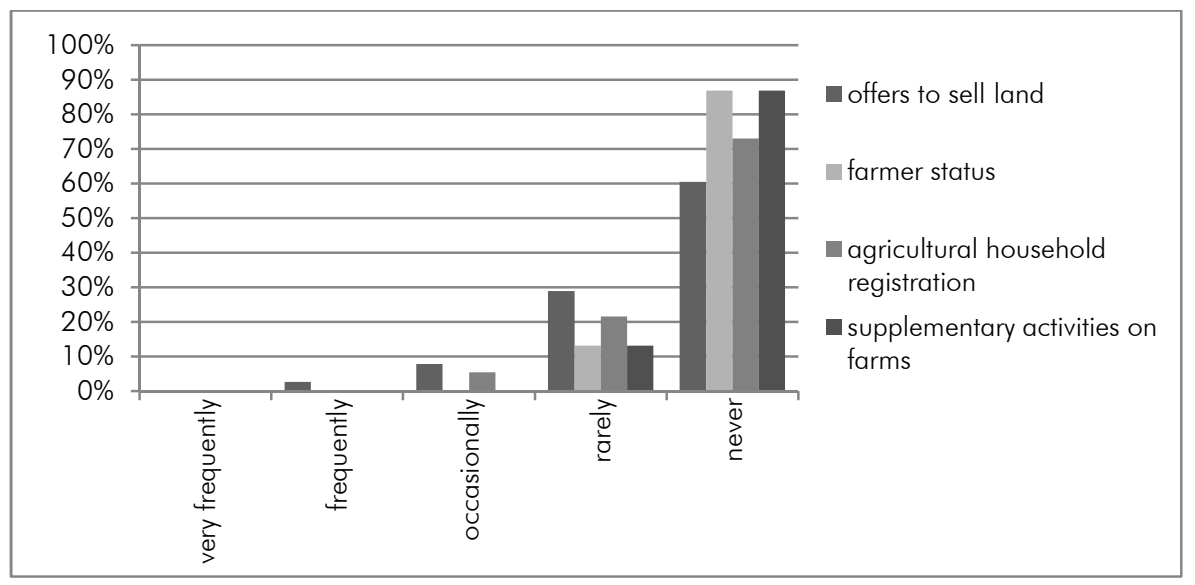

Source: Survey

\subsubsection{Business}

Similarly, for work and business matters electronic applications are not very frequent. The results of the research are very similar for the electronic notification of short-term work and for personal additional work. As Graph 7 shows, more than $80 \%$ of administrative units have not yet received such applications in electronic form. 


\section{Graph 7: E-applications received for work and business matters ( $N=39$ )}

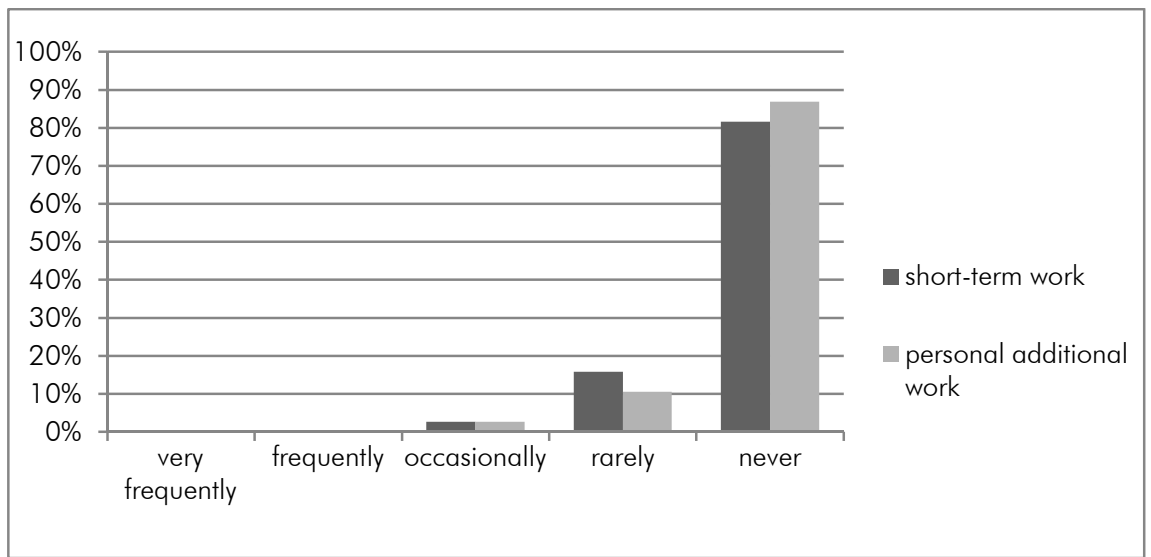

Source: Survey

\subsubsection{War veterans, victims of war violence and war invalids}

These types of application are not received with any great frequency (Graph 8). Nevertheless, a third of administrative units have already had experience dealing with war veteran status and entitlement applications (3\% occasionally and $32 \%$ rarely), while two-thirds (66\%) have not yet dealt with them. In the case of war victims and invalids, the percentage of administrative units that have received applications is very small $3 \%$ and $5 \%$ respectively), while $95 \%$ of administrative units have not received applications concerning war invalids.

\section{Graph 8: E-applications received for matters relating to war veterans, victims} of war violence and war invalids $(N=39)$

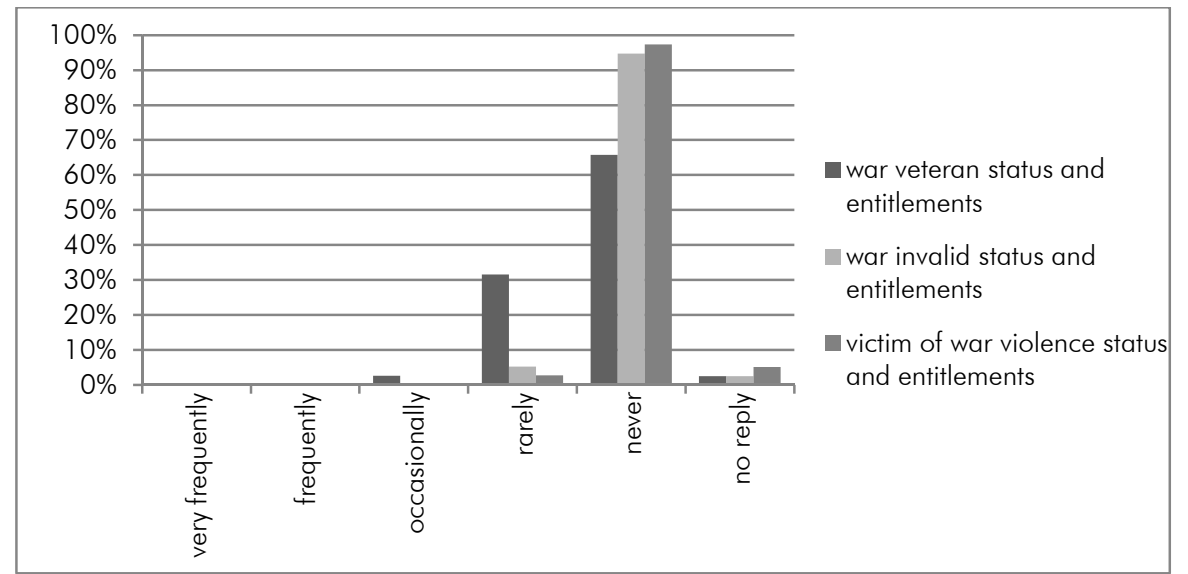

Source: Survey 


\subsubsection{Other areas}

Other areas relate primarily to the provision of public information (Graph 9), which is an individual that right that citizens are increasingly making use of and which can be exercised in electronic form. The results show that this e-service is still not very widespread: $5 \%$ of administrative units receive such applications frequently and $24 \%$ occasionally. More than half (54\%) have already received an application in electronic form, but there are also administrative units which have not yet received such applications $(16 \%) ; 5 \%$ of administrative units did not answer this question.

Graph 9: E-requests received for public information $(N=39)$

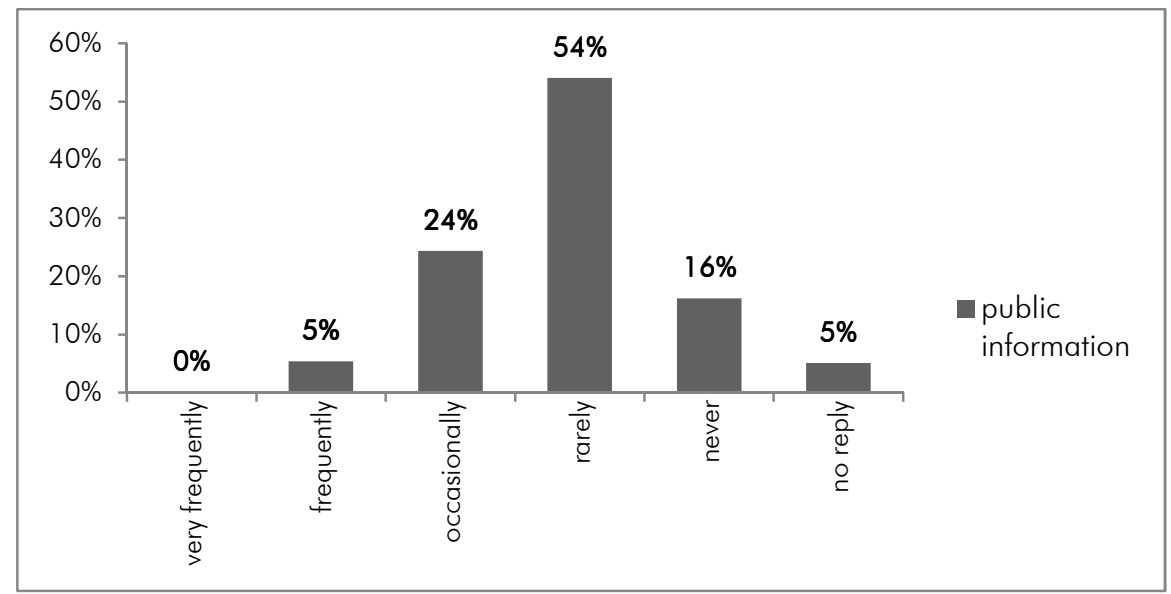

Source: Survey

Graph 10: Method of exchanging information with other public administration bodies $(\mathrm{N}=39)$

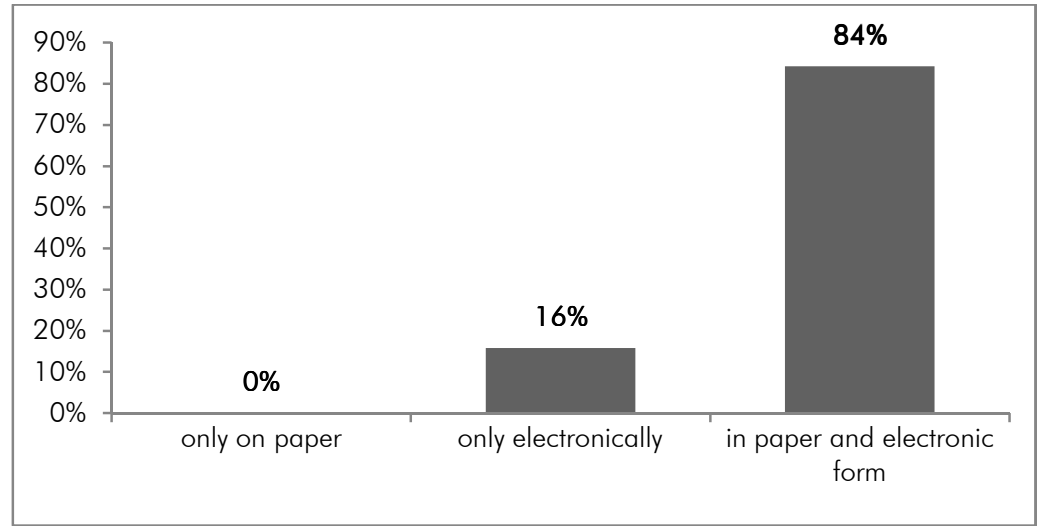

Source: Survey 
In terms of how and to what extent the administrative units conduct business with other public administration bodies, the results show (Graph 10) that e-business for internal administrative operations is more developed than for operations with external clients. Almost a fifth (16\%) of the administrative units conduct operations with other bodies exclusively by electronic means, but most (84\%) still conduct this business both on paper and electronically.

\subsection{Electronic document exchange and e-archiving}

In answer to the first question, on how they organise the exchange of data internally, $41 \%$ of administrative units replied that it is organised exclusively in electronic form, while 59\% use both paper and electronic forms (Graph 11).

\section{Graph 11: Exchange of data within administrative units $(N=39)$}

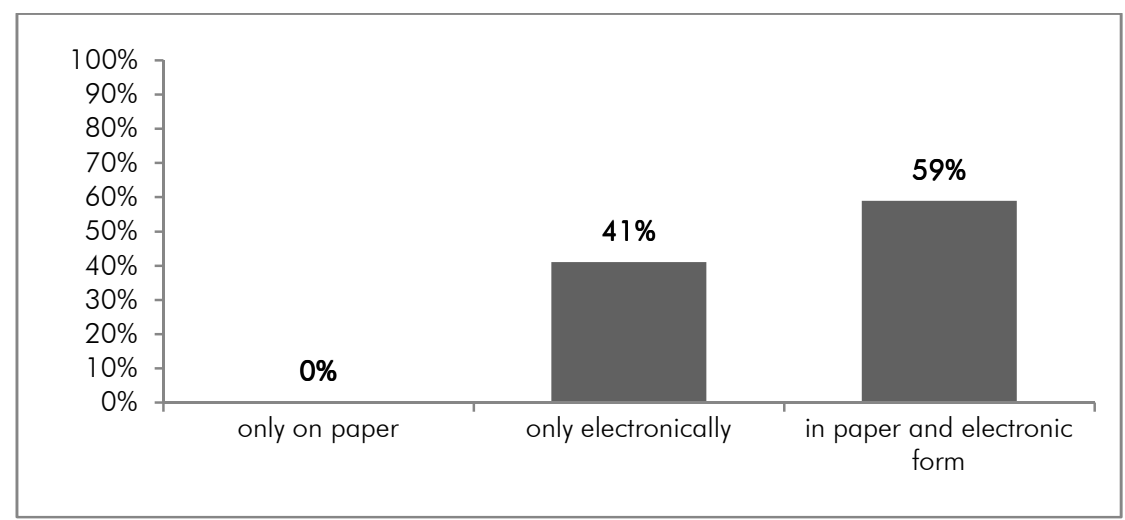

Source: Survey

The question about exchanging data with public administration bodies covers the seven different institutions and bodies with which the administrative units deal most frequently (Graph 12). The results of the research show that the highest percentage of full e-business (e-application followed up with an e-reply) was with ministries (95\%), while $28 \%$ responded to e-applications in paper form and the same proportion responded in electronic form to paper applications. The percentage of communication solely in paper form is still high (36\%).

Administrative units conduct two-way e-business with municipalities to a lesser extent (54\%): where the application is electronic, $23 \%$ of administrative units reply on paper, while $41 \%$ of administrative units reply to paper applications in electronic form. Municipalities (along with 
inspectorates) are the bodies with which most administrative units (62\%) communicate solely in paper form, while one administrative unit communicates with them on paper irrespective of the format of the application.

With the Tax Administration (DURS) a total of $69 \%$ of administrative units conduct business solely in e-form, while $14 \%$ reply to e-applications on paper and $19 \%$ reply to paper applications in electronic form. Half (52\%) reply to paper applications in paper form.

The administrative units' business with inspectorates is also not marked by a very high percentage of electronic operations (54\%); $13 \%$ still reply to e-applications in paper form, $23 \%$ reply to paper applications in electronic form and $62 \%$ still conduct operations on paper in both directions.

The proportion of administrative units that communicate with social work centres electronically in both directions is $68 \%$; $27 \%$ reply to eapplications on paper, somewhat more reply to paper applications electronically $(35 \%)$, while almost half $(46 \%)$ of communication is still carried out in paper form, and one administrative unit replies to all applications exclusively in paper form.

Operations with the police follow a similar pattern: $68 \%$ of administrative units conduct e-business in both directions, $14 \%$ send a paper reply in response to e-applications, while 19\% send an electronic reply in response to a request on paper. Some $46 \%$ of administrative units respond to a paper application from the police in paper form, while $5 \%$ respond exclusively on paper irrespective of the format in which the application is received.

The administrative units' operations with the Pension and Disability Insurance Institute (ZPIZ) also follow exactly the same pattern. Full electronic data exchange takes place in $66 \%$ of cases, while $16 \%$ of administrative units respond to e-applications on paper and $32 \%$ send electronic answers to paper applications, while 45\% conduct their operations on paper in both directions.

76 Uprava, letnik IX, 1/2011 


\section{Graph 12: Method of exchanging data with selected public administration} bodies $(\mathrm{N}=39)$

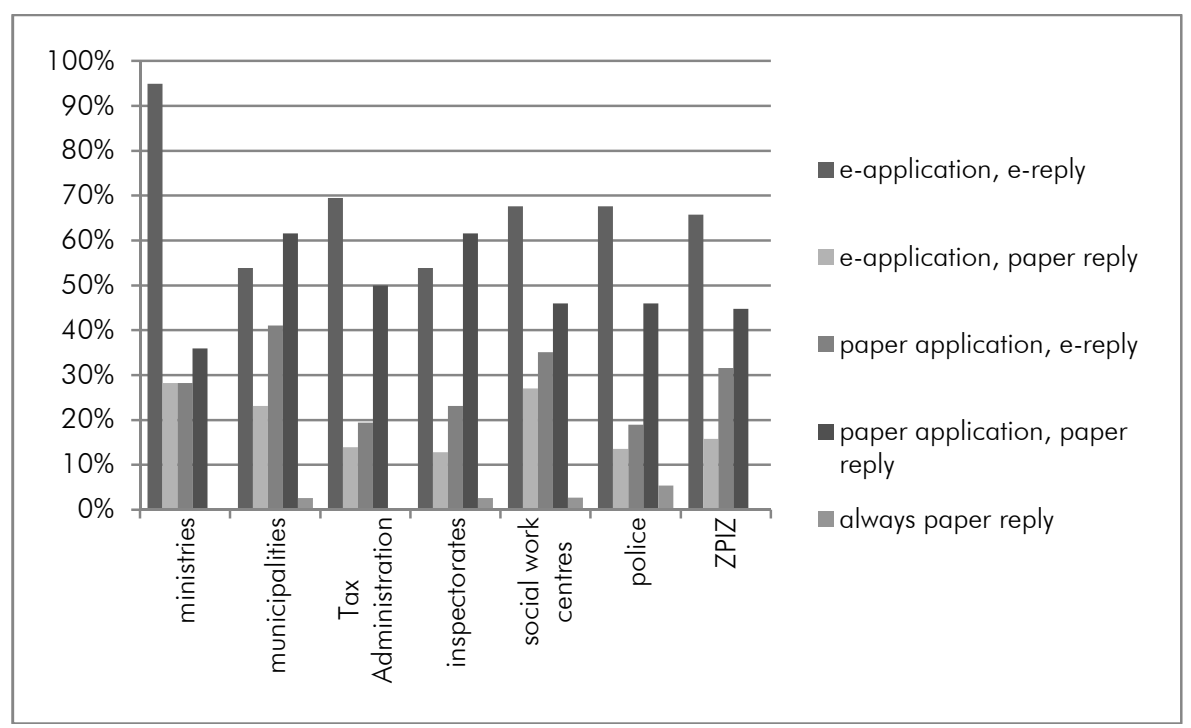

Source: Survey

One point in the questionnaire referred to the electronic storage of documents (Graph 13). It is encouraging to note that $87 \%$ of administrative units scan incoming documents, and $10 \%$ plan to do so. On the question of the internal rules under which, by law, the internal operations of the bodies concerned should be regulated, the answers were more divided: $29 \%$ of administrative units already have such rules; $45 \%$ do not and $26 \%$ are planning to adopt them. The answers to the question about cooperation with other bodies (ministries, archives, etc.) on long-term electronic storage of documents were also varied: $29 \%$ of administrative units are already cooperating with other bodies, $42 \%$ are not and almost a third (29\%) are planning to do so. 
Graph 13: Electronic document storage $(N=39)$

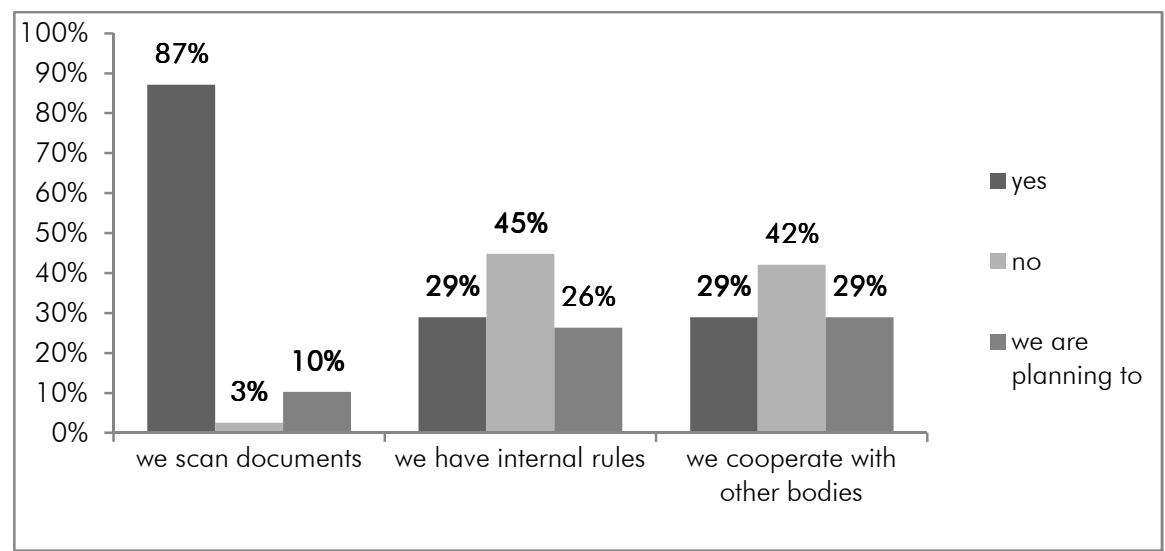

Source: Survey

Various difficulties and obstacles are encountered in the development of modern systems and technologies in administration, so it is interesting to obtain the administrative units' views on the obstacles they themselves face in introducing or implementing e-business (Graph 14). Several responses were possible, but the one that stood out was that the biggest problem is the lack of ICT (67\%). Other responses were less prominent: $28 \%$ of public officials in administrative units believe that a lack of knowledge is one of the key problems; $21 \%$ of administrative units see difficulties in the lack of finance; $26 \%$ consider the problem to be legislation; three administrative units (8\%) stated that they saw no problems in the implementation of e-business and 15\% stated that they saw no problems other than those already mentioned, so these responses were not taken into account in processing this question. 18\% of administrative units mentioned other obstacles, such as: too little awareness of e-business on the part of clients; employees adapting too slowly to the new information technology; impossibility of delivering to a secure address because in spite of the legislation adopted, an appropriate IT solution is not yet in place, etc. 
Graph 14: Problems with e-business ( $N=39)$

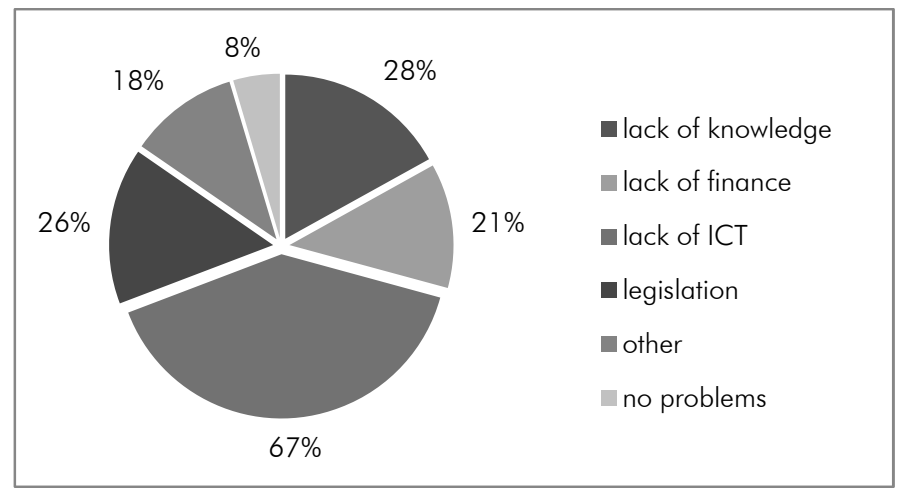

Source: Survey

\section{Analysis of the results of the research}

A comprehensive and reliable assessment of the state of egovernment in Slovenia would require much wider-ranging empirical research, encompassing all the key areas of the public sector. Therefore this research based solely on the administrative units is of limited value and the results produced cannot be generalised without reservations. Nevertheless, we can draw important conclusions from the example of the administrative units as they carry out around three-quarters of all firstinstance administrative procedures, and a large and important part of the e-business of citizens and businesses is conducted through them. We can summarise the results obtained into the following findings:

- the administrative units' use of e-services for external users (citizens and businesses) is still in its infancy, as fewer than half of the administrative units receive e-applications daily. The majority of eapplications are received for matters relating to internal affairs, with the most frequently requested services being vehicle registration extensions and access to the central register,

- in all the other areas of the administrative units' operations, which generally involve more complicated procedures, the environment and physical planning, agriculture, business, etc., e-applications are still very rare, and most administrative units have never received an electronic application,

- electronic delivery of documents is still only just beginning. More than half of the administrative units have not even attempted it as 
they do not have a secure mailbox with the Slovenian Post Office, which is a prerequisite for such delivery,

- e-business between administrative bodies is far more advanced, most notably with government ministries, with whom business is already mostly conducted electronically, and also most administrative units already operate electronically with other bodies that are important for their operations, such as municipalities, the Tax Administration, inspectorates and social work centres.

It was expected that the administrative units would have a high percentage of e-business with ministries, not least because they perform many tasks that involve the ministries' areas of work. It is therefore in the ministries' own interest for such operations to be modernised rapidly and on a regular basis and for modern ICT to be introduced so as to make the work easier for all employees. Municipalities are a part of local government. In terms of e-business it is known that local government lags behind the state administration, and so the results of the research are not surprising. The results for the police, social work centres, Tax Administration and the Pension and Disability Insurance Institute (ZPIZ) are more equal, but the administrative units' e-business with inspectorates is lagging behind. The Tax Administration is an important business partner of the administrative units and so we can expect electronic operations between them to increase in future.

The results for electronic storage activities are also interesting. On the one hand it is encouraging that a large majority (87\%) of administrative units already scan all incoming documents, meaning that the administrative units' internal operations could be conducted almost entirely in electronic form, but on the other hand it is surprising that only just over a quarter of administrative units have internal rules that actually regulate the handling of such documents.

All these findings should be summarised and compared with the results that Slovenia has achieved in recent years in international measurements and comparisons. Unfortunately, we cannot compare directly the results of our research with the situation in other countries because the data is either unavailable or not comparable. Most international organisations and institutions which evaluate the level of development of e-government in individual countries, either on a global 
level (United Nations, World Bank, certain universities, etc.) or within the EU, do not directly measure the use of e-government services, focusing instead on the supply of such services. The only data we can use to compare the use of e-services is that published by Eurostat (Eurostat, 2008), according to which Slovenia is somewhere around the average when it comes to the use of public e-services.

We can, however, draw some conclusions indirectly. The discrepancy between Slovenia's rankings under the Capgemini measurements (Capgemini, 2007; Capgemini, 2009), the measurements of certain other international organisations, such as the United Nations (UN E-Government Survey, 2008; The Economist, 2007) and our findings is striking. On most international rankings of e-government Slovenia comes around 30th place for world rankings and around average for European rankings. It is only on the Capgemini measurements that we are at the very top (2nd place in 2007; 5th place in 2009) among EU countries. It is surprising, for example, that according to these measurements Slovenia records a score of $95 \%$ for "fully online availability" of services. This would mean that all the services measured are developed to the fourth or fifth stage on the five-stage sophistication scale. But in our research we found that more than half of the administrative units are not even equipped to provide services at this level because they do not have a secure mailbox, which casts doubt on this data, and hence on our ranking according to these measurements.

In short, we believe that in terms of the level of development of its egovernment, when viewed overall, Slovenia is a lot closer to the European average than to the top, as has often been heard in recent years.

\section{Conclusion}

How can the use of these services be increased and how, in general, can further development be accelerated? There is no simple answer. The issue needs to be looked at on a number of levels. To begin with, internet access, which is essential for obtaining information and performing many electronic services, needs to be provided to as many people as possible. According to Eurostat research carried out in 2008, Slovenia is around the EU average in terms of internet use, but well below average when it comes to bridging the "digital divide". E-government has so far made a good start, but it appears that the public are not very familiar with it and with the possibilities it offers. E-services need to be presented and offered 
to people in a more friendly, transparent and easy-to-use manner. Officials working in the administrative units themselves, as well as in other public administration bodies, are not overly familiar with e-government and its capabilities, so it is hard to expect them to point users in the direction of these services.

In terms of their role in relation to external users of administrative services, the administrative units are a vital part of the development of e-government and e-business in Slovenia. Through their services and more active cooperation with many other public administration bodies, and particularly through their example and consistent use of modern technological solutions, the administrative units can help develop and expand the use of e-business in all areas of public administration.

It is clear that Slovenia still has very much to do for its e-government to really take off in practice at the operational, service-provision level. We believe that too little has been done so far, particularly in terms of promoting e-government and developing services that would genuinely facilitate users' contact with the administration.

Mitja Jelenic graduated from the Faculty of Administration, University of Liubliana in 2009. He works as an advisor in the field of e-operations and the use of modern IT at the Administrative unit Novo mesto.

Prof. dr. Mirko Vintar is professor of Information systems in Public Administration and E-governemnt. For over 20 years his work has dealt with the informatisation of public administration, with a major focus on the development of e-government in recent years. He has been managing a series of national and international research and development projects in this field. He was/is a member of numerous national and international scientific and profession/ committies and working groups involved in the research of this field (EGPA, Study Group on Informatisation of Public Administration, IFIP. WG 8.5, NISPAcee-WG on E-government). In 1993-2002 he was the chief editor of Journal Uporabna informatika (Applied Informatics). 


\section{References}

- Bannister, F. (2007). The curse of benchmark: an assessment of the validity and value of e-government comparison. International Review of Administrative Sciences, 73(2), pp. 171-188.

- Capgemini. (2006). Online Availability of Public Services: How Is Europe Progressing? Web Based Survey on Electronic Public Services, Report of the 6th Measurement. Belgium: CapGemini.

- Capgemini. (2007). The User Challenge Benchmarking The Supply of Online Public Services, 7th Measurement. European Commission Directorate General for Information Society and Media. Belgium: Capgemini.

- Capgemini. (2009). Benchmark Measurment of European e-Government services. Belgium: Capgemini.

- Economist. (2007). The 2007 e-readiness rankings, Raising the bar. A white paper from the Economist Intelligence Unit. London: The Economist.

- Eurostat. (2007a). E-government usage by individuals - total - Percentage of individuals aged 16 to 74 using the Internet for interaction with public authorities. Luxembourg: Eurostat.

- Eurostat. (2007b). Share of individuals using the Internet for interacting with public authorities. Luxembourg: Eurostat.

- Grad, J., \& Vintar, M. (Eds.). (2004). E-uprava: Izbrane razvojne perspektive. Ljubliana: Fakulteta za upravo.

- Leben, A., \& Kunsteli, M. (2004). Trendi razvoja e-uprave v Sloveniii. Uprava, II(2), pp. 7-29.

- Seznam trenutno odprtih predalov Pošte Slovenije. Pridoblieno 25. 07. 2009, s http://moja.posta.si/files/varni_postni_predali.pdf

- Strategija e-uprave RS za obdobje od leta 2006 do leta 2010 (SEP-2010). Pridoblieno februar 2006, s http://e-uprava.gov.si/eud/e-uprava/sep2010\% 20130206.doc.

- UN. (2008). From E-Government to Connected Governance. Department of Economic and Social Affairs, Division for Public Administration and Development Management. New York: United Nations.

- Uredba o upravnem poslovanju. Ur. I. RS, št. 20/05, 106/05, 30/06, 86/06, 32/07, 63/07, 115/07, 122/07, 31/08, 35/09.

- Uredba o varstvu dokumentarnega in arhivskega gradiva. Ur. I. RS, št. 86/06.

- UNDPEPA. (2002). Benchmarking E-Government: A Global Perspective. Assesing the Progress of the UN Member States. New York: United Nations 
Division for Public Economics and Public Administration and American Society for Public Administration.

- World Economic Forum. (2006). Global Information Technology Report 2006-2007. Geneva: World Economic Forum.

- Vintar, M., \& Leben, A. (2000). Sistemsko tehnološki okviri za uvajanje elektronskega poslovanja državne uprave: Od portirja do portala. VII. dnevi slovenske uprave. Portorož (pp. 355-369). Ljubljana: Visoka upravna šola.

- Vintar, M., et al. (2006). Merienje zadovoljstva uporabnikov e-uprave: Razširjeni povzetek. Ljubliana: Fakulteta za upravo.

- Zakon o dostopu do informacij javnega značaja - uradno prečiščeno besedilo (ZDIJZ-UPB2). Ur. list RS, št. 51/06, 117/06-ZDavP-2.

- Zakon o varstvu dokumentarnega in arhivskega gradiva ter arhivih (ZVDAGA). Ur. I. RS, št. 30/06. 